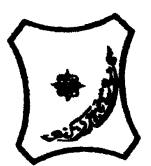

Bayero Journal of Pure and Applied Sciences, 11(1): 168 - 173

Received: January, 2018

Accepted: May, 2018

ISSN $2006-6996$

\title{
SYNTHESIS AND CHARACTERISATION OF SOME MIXED LIGANDS ADDUCTS OF BENZOYLACETONE AND SALICYLALDEHYDE
}

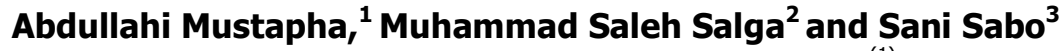 \\ Department of Chemistry, Federal University Dutse. ${ }^{(1)}$ \\ Department of Pure and Industrial Chemistry Umaru Musa Yar'adua University Katsina ${ }^{(2)(3)}$ \\ Correspondence author: sani.sabo@umyu.edu.ng
}

\begin{abstract}
$A$ series of four mixed ligand complexes were synthesized by reacting benzoylacetone and salicylaldehyde with different metal chlorides in ethanolic medium. The complexes have been characterized by molar conductance measurements and spectral techniques such as IR and Uv-visible electronic spectra. Decomposition temperature was also determined. The results indicated that the compounds have bands at 400-500 $\mathrm{cm}^{-1}$, with very sharp melting points. This proved the formation of metal-oxygen bond, purity and high thermal stability of the compounds that could lead to a high antimicrobial activity.
\end{abstract}

Keywords: Adduct Synthesis, Ligands, and Complexes

\section{INTRODUCTION}

The chemistry of mixed ligand complexes has received interest in recent decades due to the wide applications of coordination compounds in various fields. Mixed ligand complexes appeared to be relevant in biological fluids, create specific structures and manifest themselves as enzyme-metal ion-substrate complexes (Reddy et a/2005).

$\mathrm{N}$-Anilinoacetohydrazobenzoylacetone $\left(\mathrm{H}_{2} \mathrm{~L}\right)$ and their manganese(II), cobalt(II), nickel(II), copper(II) and zinc(II) complexes have been synthesized and characterized by IR, electronic spectra, molar conductivities, thermal analyses and magnetic susceptibilities. Binuclear complexes with molar ratios of $(M: L)=2: 1$ are formed. The IR spectra of these compounds showed that the ligand $\left(\mathrm{H}_{2} \mathrm{~L}\right)$ coordinates to the metal ions in a tetradentate manner with $\mathrm{O}_{2} \mathrm{~N}_{2}$ as donor sites in $\mathrm{Mn}(\mathrm{II}), \mathrm{Co}(\mathrm{II}), \mathrm{Ni}(\mathrm{II})$ and $\mathrm{Zn}(\mathrm{II})$ complexes while in the $\mathrm{Cu}$ (II) complexes the ligand coordinated as bidentate via $\mathrm{N}$ and $\mathrm{O}$ donor atoms. The copper(II) complexes, also, shows higher antibacterial activity towards gram positive ( $\mathrm{G}+$ ) bacteria Bacillus subtilis than the ligand and other complexes while $\mathrm{Mn}$ (II) complex shows higher antifungal activity than the free ligand (Kashar, 2014).

Aliyu and Mustapha (2009) reported the synthesis of some oxovanadium (IV) complexes of acetylacetone, dibenzoylmethane, 2thionyltrifluoroacetone, Triflouroacetylacetone and benzoylacetone. The complexes were characterized by elemental analysis, molar conductance, decomposition temperature, solubility and infrared spectral studies with $1: 2 \mathrm{M}: \mathrm{L}$ ratio.

Dinuclear complexes from salicylaldehyde and 2aminophenol with $\mathrm{Cu}(\mathrm{II}), \mathrm{Ni}(\mathrm{II})$ and $\mathrm{Co}(\mathrm{II})$ and $\mathrm{Fe}(\mathrm{III})$ were synthesized and characterized by IR, UV-visible and elemental analysis. The mass spectral data obtained was in good agreement with the result obtained from the thermogravimetric analysis (TGA) in accordance with its fragmentation pattern (Bhatt, 2008). The magnetic properties of these complexes were studied and the probable mechanism for the formation of the complexes was proposed.

\section{MATERIALS AND METHODS}

Materials: Benzoylacetone (Aldrich), Salicylaldehyde (Aldrich), Manganese (II) Chloride, Iron (III)Chloride (lobachem), Nickel (II) chloride, copper(II) chloride, ethanol (Glanson chemicals Itd), chloroform (cartvalues Itd), solvents were AnalaR and were used as supplied.

Analytical methods and Physical measurements: The compounds were analyzed for IR using CARY 630 FT-IR, thermo Nicolet instrument in the range of 4004000. The UV spectral measurements was carried out using T60 spectrophotometer The solubility of each metal complex was tasted using various non-polar solvents like hexane and distilled water. While the polar solvents includes chloroform, acetic acid, acetone etc. Molar conductances were measured at room temperature in DMSO using digital conductivity meterT60. The melting points of the complexes were also carried out using Barnstead electronic thermal -IA9110.

Synthesis of Copper (II) complex with mixed ligand

To an ethanolic solution $(10 \mathrm{ml})$ of $\mathrm{CuCl}_{2} \cdot 2 \mathrm{H}_{2} \mathrm{O}(5.24$ $\mathrm{mmol}, 0.893 \mathrm{~g})$, an ethanolic solutions $(10 \mathrm{ml})$ of benzoylacetone $(5.24 \mathrm{mmol}, 0.85 \mathrm{~g})$ and salicyaldehyde $(5.24 \mathrm{mmol}, 0.64 \mathrm{~g})$ were added with constant stirring. The reaction mixture was stirred for about 40 minutes. The precipitate formed was filtered, washed with ethanol and dried under reduced pressure. (Agrawal, etal 2003) 


\section{Synthesis of Manganese (II) complex with mixed ligand}

To an ethanolic solution $(10 \mathrm{ml})$ of $\mathrm{MnCl}_{2} \cdot 4 \mathrm{H}_{2} \mathrm{O}(5.24$ $\mathrm{mmol}, 1.03 \mathrm{~g})$, an ethanolic solution $(10 \mathrm{ml})$ of benzoylacetone $(5.24 \mathrm{mmol}, 0.85 \mathrm{~g})$ and salicyaldehyde (5.24 mmol, $0.64 \mathrm{~g}$ ) were added with constant stirring. The reaction mixture was stirred for about 40 minutes. No precipitate was obtained. Then, few drops of Triethylamine solution $(4 \mathrm{ml})$ was added drop wise to the above reaction mixture to raise the $\mathrm{pH}$ to 6.0 . The solution was stirred and refluxed for 3-4 hrs and the reaction mixture was kept at room temperature. The solution, was filtered, washed with ethanol and dried properly under reduced pressure. (Agrawal, et-a/2003)

\section{Synthesis of Nickel (II) complex with mixed ligand}

To an ethanolic solution $(10 \mathrm{ml})$ of $\mathrm{NiCl}_{2}(5.24 \mathrm{mmol}$, $0.68 \mathrm{~g})$, an ethanolic solution $(10 \mathrm{ml}$ ) of benzoylacetone $(5.24 \mathrm{mmol}, 0.85 \mathrm{~g})$ and salicyaldehyde $(5.24 \mathrm{mmol}$, $0.64 \mathrm{~g}$ ) were added with constant stirring. The reaction mixture was stirred for about 40 minutes. No precipitate was obtained. Then, few drops of Triethylamine solution $(4 \mathrm{ml})$ was added drop wise to the above reaction mixture to raise the $\mathrm{pH}$ to 6.0 . The solution was stirred and refluxed for 3-4 hrs and the reaction mixture was kept on room temperature. The precipitate was settled down. The solution, was filtered, washed with ethanol and dried properly under reduced pressure. (Agrawal, et-a/2003)

\section{Synthesis of Iron (III) complex with mixed ligand}

To an ethanolic solution $(10 \mathrm{ml})$ of $\mathrm{FeCl}_{3} \cdot 6 \mathrm{H}_{2} \mathrm{O}(5.24$ $\mathrm{mmol}, 0.85 \mathrm{~g})$, an ethanolic solution $(10 \mathrm{ml})$ of benzoylacetone $(5.24 \mathrm{mmol}, 0.85 \mathrm{~g}$ ) and salicyaldehyde $(5.24 \mathrm{mmol}, 0.64 \mathrm{~g})$ were added with constant stirring. The reaction mixture was stirred for about 40 minutes. No precipitate was obtained. Then, few drops of Triethylamine solution $(4 \mathrm{ml})$ was added drop wise to the above reaction mixture to raise the $\mathrm{pH}$ to 6.0 . The solution was stirred and refluxed for 3-4 hrs and the reaction mixture was kept on room temperature. The resulting solution, was filtered, washed wit ethanol and dried properly under reduced pressure (Agrawal et al., 2003).

\section{RESULTS AND DISCUSSION}

Table 1 provides some of the physical parameters that serves as supporting evidence for the proposed complexes.

Mixed ligand complexes of $\mathrm{Cu}$ (II), Fe (III), Mn (II), and $\mathrm{Ni}$ (II) have been prepared by the reaction of manganese (II) chloride tetrahydrate, ferric (III) chloride hexahydrate, nickel(II) chloride, zinc(II) chloride with the ligands Salicylaldehyde and Benzoylacetone in 1:1:1 ratio. The resulting synthesized complexes were coloured solids and have a relatively high decomposition point.

The complexes of copper (II), Iron (III), Manganese (II) and Nickel (II) gave decomposition temperatures of $235^{\circ} \mathrm{C}, 220^{\circ} \mathrm{C}, 239^{\circ} \mathrm{C}$ and $239^{\circ} \mathrm{C}$ respectively. These high decomposition temperatures revealed that the complexes are thermally stable. However, the complexes appeared to have dark brown, reddish, light orange and pale green colours respectively.

The complexes showed variable solubilities in different solvents with very few showing slight solubility in the same solvent used. However, all the complexes were soluble in DMSO (Table 2) being it a polar aprotic solvent, it has the ability to dissolve a wide range of solutes and also has a high di-electric constant.

Being DMSO the only solvent that can dissolve the compounds, it was used to measure the molar conductivities of the compounds at $10^{-3} \mathrm{M}$ solutions (Table 4). The results of conductivity measurements showed that the $\mathrm{Mn}(\mathrm{II}), \mathrm{Fe}(\mathrm{III}), \mathrm{Ni}(\mathrm{II})$ and $\mathrm{Cu}(\mathrm{II})$ complexes, have values in the range 49-90.6 $\Omega^{-1} \mathrm{~mol}^{-1}$ $\mathrm{cm}^{2}$. This indicates that they are non-electrolytes, the slight increase in the conductance values observed, may be due to some solvolysis or dissociation (El-Qisairi et al., 2007). Moreover, it is reported that, in a complex, the positive charge of the metal is partially shared with the donor atoms present in the ligand, and there may be $n$-electron delocalization over the whole complex (Sanap et al., 2013).

The UV-visible spectra of the mixed ligand complexes were also recorded in DMSO in the region 300 to $600 \mathrm{~nm}$. All the complexes showed peaks in the UV region with wavelengths in the range $300-400 \mathrm{~nm}$ this may be assigned to the $\Pi-\Pi^{*}$ transition of the chromophores, while bands above $400 \mathrm{~nm}$ may be assigned to charge transfer transition (Table 4). The above Uv-visible results of the complexes conformed to the literature report by (Mustapha et al., 2014).

In addition, the IR spectra of all the complexes have been studied and assignments were given to the manifested bands regions. The complexes of Fe(III), $\mathrm{Mn}$ (II) and $\mathrm{Cu}(\mathrm{II})$ showed absorption at the bands regions of $2080 \mathrm{~cm}^{-1}, 2143 \mathrm{~cm}^{-1}$ and $2119 \mathrm{~cm}^{-1}$ respectively, this can presumably be attributed to the aromatic $V(C-H)$ stretching (Malathy, 2004). The strong intensity bands that appeared at $1624 \mathrm{~cm}^{-1}$ for $\mathrm{Mn}$ (II), $1617 \mathrm{~cm}^{-1}$ for $\mathrm{Fe}$ (III), $1624 \mathrm{~cm}^{-1}$ for $\mathrm{Ni}(\mathrm{II})$ and $\mathrm{Cu}(\mathrm{II}) \mathrm{cm}^{-}$ ${ }^{1}$ are assigned to $\mathrm{V}(\mathrm{C}=\mathrm{O})$ stretching vibration (Halli et al., 2012). A band in the region $1419-1522 \mathrm{~cm}^{-1}$ can be ascribed to $\forall(\mathrm{C}=\mathrm{C})$ bond. This can be presumed that the anionic ligand is coordinated to metal in the tautomeric form (Ahmadzadeh et al., 2014) as shown in Table 3 Bands for $V(M-O)$ were observed in the spectra of $\mathrm{Cu}$ (II) complex at $419 \mathrm{~cm}^{-1}$, Fe(III) at $472 \mathrm{~cm}^{-1}$ region, $\mathrm{Ni}(\mathrm{II})$ complex at $419 \mathrm{~cm}^{-1}$ and $\mathrm{Mn}$ (II) at $419 \mathrm{~cm}^{-}$ 1 . This complied with the reported literature (Dnyaneshwar et al., 2014). Therefore, from the IR spectra it is concluded that the ligands behaved as monobasic or neutral ligands coordinated to the metal ion via carbonyl oxygen of benzoylacetone and enolic oxygen of the salicylaldehyde as shown in the diagram below. 
Bajopas Volume 11 Number 1 June, 2018

Table 1: Physical measurements

\begin{tabular}{|c|c|c|c|c|c|c|c|c|c|c|c|}
\hline $\mathbf{S} / \mathbf{N}$ & Compound & $\begin{array}{l}\text { Empirical } \\
\text { Formula }\end{array}$ & Mwt. & $\begin{array}{l}\text { M.P } \\
\left({ }^{\circ} \mathrm{C}\right)\end{array}$ & $\begin{array}{l}\text { Cond. } \\
\Lambda, \quad \Omega-1 \\
\text { mol-1 } \\
\mathrm{cm}^{2}\end{array}$ & $\begin{array}{l}\text { \%C } \\
\text { found }\end{array}$ & $\begin{array}{l}\text { \%H } \\
\text { found }\end{array}$ & $\begin{array}{l}\text { \%Cl } \\
\text { found }\end{array}$ & $\begin{array}{l}\text { \%O } \\
\text { found }\end{array}$ & $\begin{array}{l}\text { \% } M . \\
\text { found }\end{array}$ & Color \\
\hline 1 & $\begin{array}{l}\text { Mn(II) } \\
\text { complex }\end{array}$ & {$\left[\mathrm{MnC}_{17} \mathrm{H}_{15} \mathrm{ClO}_{4}\right]$} & 373.00 & 239 & 52.9 & 54.64 & 4.05 & 9.49 & 17.13 & 14.74 & $\begin{array}{l}\text { Light } \\
\text { Orange }\end{array}$ \\
\hline 2 & $\begin{array}{l}\text { Fe(III) } \\
\text { Complex }\end{array}$ & {$\left[\mathrm{FeC}_{22} \mathrm{H}_{15} \mathrm{Cl}_{3} \mathrm{O}_{5}\right]$} & 408.97 & 220 & 90.6 & 49.79 & 3.69 & 17.29 & 15.61 & 13.62 & $\begin{array}{l}\text { Reddish } \\
\text { Brown }\end{array}$ \\
\hline 3 & $\mathrm{Ni}(\mathrm{II})$ complex & {$\left[\mathrm{NiC}_{17} \mathrm{H}_{15} \mathrm{ClO}_{4}\right]$} & 377.44 & 239 & 51.2 & 54.10 & 4.01 & 9.39 & 16.96 & 15.55 & Pale green \\
\hline 4 & $\mathrm{Cu}$ (II) complex & {$\left[\mathrm{CuC}_{17} \mathrm{H}_{15} \mathrm{ClO}_{4}\right]$} & 382.30 & 235 & 49.6 & 53.42 & 3.95 & 9.27 & 16.74 & 16.62 & Dark brown \\
\hline
\end{tabular}

Key; Mwt: Molecular weight, Cond: Conductivity

Table 2: Solubility of the complexes.

\begin{tabular}{lllll}
\hline Solvents & Cu(II) complex & Fe(III) complex & $\begin{array}{l}\text { Mn } \\
\text { (II)complex }\end{array}$ & $\begin{array}{l}\text { Ni } \\
\text { (II)complex }\end{array}$ \\
\hline Distilled water & S & IS & S & SS \\
Ethanol & IS & SS & S & S \\
Methanol & S & SS & S & S \\
Acetone & S & S & S & SS \\
Chloroform & S & SS & S & S \\
N-hexane & S & SS & S & S \\
Dimethylsulfoxide & S & S & S &
\end{tabular}

$\mathrm{S}=$ Soluble, $\mathrm{SS}=$ slightly soluble, IS=Insoluble 
Bajopas Volume 11 Number 1 June, 2018

Table 3: Infrared spectra data of the complexes

\begin{tabular}{lllll}
\hline Compounds & $\boldsymbol{V}(\mathbf{C}=\mathbf{0}) \mathbf{c m}^{-\mathbf{1}}$ & $\boldsymbol{V} \mathbf{C}=\mathbf{C}) \mathbf{c m}^{\mathbf{- 1}}$ & $\boldsymbol{V ( C - H ) \mathbf { c m } ^ { - \mathbf { 1 } }}$ & $\boldsymbol{v}(\mathbf{M - O}) \mathbf{c m}^{-\mathbf{1}}$ \\
\hline$\left[\mathrm{MnL}_{1}\right]\left(\mathrm{C}_{17} \mathrm{H}_{15} \mathrm{ClO}_{4}\right)$ & $1624_{(\mathrm{s})}$ & $1419_{(\mathrm{s})}$ & $2143_{(\mathrm{m})}$ & $419_{(\mathrm{w})}$ \\
{$\left[\mathrm{FeL}_{2}\right]\left(\mathrm{C}_{22} \mathrm{H}_{15} \mathrm{Cl}_{3} \mathrm{O}_{5}\right)$} & $1617_{(\mathrm{s})}$ & $1522_{(\mathrm{s})}$ & $2080_{(\mathrm{m})}$ & $472_{(\mathrm{w})}$ \\
{$\left[\mathrm{NiL}_{3}\right]\left(\mathrm{C}_{17} \mathrm{H}_{15} \mathrm{ClO}_{4}\right)$} & $1624_{(\mathrm{s})}$ & $1457_{(\mathrm{w})}$ & - & $419_{(\mathrm{w})}$ \\
{$\left[\mathrm{CuL}_{4}\right]\left(\mathrm{C}_{17} \mathrm{H}_{15} \mathrm{ClO}_{4}\right)$} & $1624_{(\mathrm{s})}$ & $1510_{(\mathrm{m})}$ & $2119_{(\mathrm{b})}$ & $456_{(\mathrm{m})}$
\end{tabular}

Key; $\mathrm{S}=$ strong, $\mathrm{m}=$ medium, $\mathrm{b}=$ broad

Table 4: Uv-visible spectral data of the complexes

\begin{tabular}{lllllll}
\hline S/N & $\begin{array}{l}\text { Wave } \\
\text { length (nm) }\end{array}$ & $\begin{array}{l}\text { Cu(II) } \\
\text { Absorbance }\end{array}$ & $\begin{array}{l}\text { complex(III) } \\
\text { Absorbance }\end{array}$ & $\begin{array}{l}\text { complex } \\
\text { Absorbance }\end{array}$ & $\begin{array}{l}\text { Complex } \\
\text { Absorbance }\end{array}$ \\
\hline 1 & 300 & 0.255 & 0.235 & 0.442 & 0.222 \\
2 & 320 & 0.232 & 0.212 & 0.345 & 0.232 \\
3 & 340 & 0.212 & 0.215 & 0.331 & 0.205 \\
4 & 360 & 0.225 & 0.477 & 0.206 & 0.324 \\
5 & 380 & 0.354 & 0.244 & 0.285 & 0.424 \\
6 & 400 & 0.476 & 0.213 & 0.124 & 0.357 \\
7 & 420 & 0.205 & 0.173 & 0.164 & 0.259 \\
8 & 440 & 0.234 & 0.127 & 0.163 & 0.171 \\
9 & 460 & 0.324 & 0.124 & 0.122 & 0.288 \\
10 & 480 & 0.166 & 0.164 & 0.145 & 0.211 \\
11 & 500 & 0.134 & 0.163 & 0.155 & 0.123 \\
12 & 520 & 0.114 & 0.146 & 0.255 & 0.135 \\
13 & 540 & 0.222 & 0.155 & 0.145 & 0.112 \\
14 & 560 & 0.184 & 0.224 & 0.112 & 0.132 \\
15 & 580 & 0.127 & 0.174 & 0.178 & 0.112 \\
16 & 600 & 0.139 & 0.167 & 0.224 & 0.121 \\
\hline
\end{tabular}<smiles>CC(=O)COc1ccccc1ON(OCc1ccccc1Cl)OC(C)=O</smiles>

Figure 1: proposed structure of the complexes where ' $M$ ' represents the divalent transition metals ( $\mathrm{Cu}$, $\mathrm{Mn}$, and $\mathrm{Ni}$ ) 


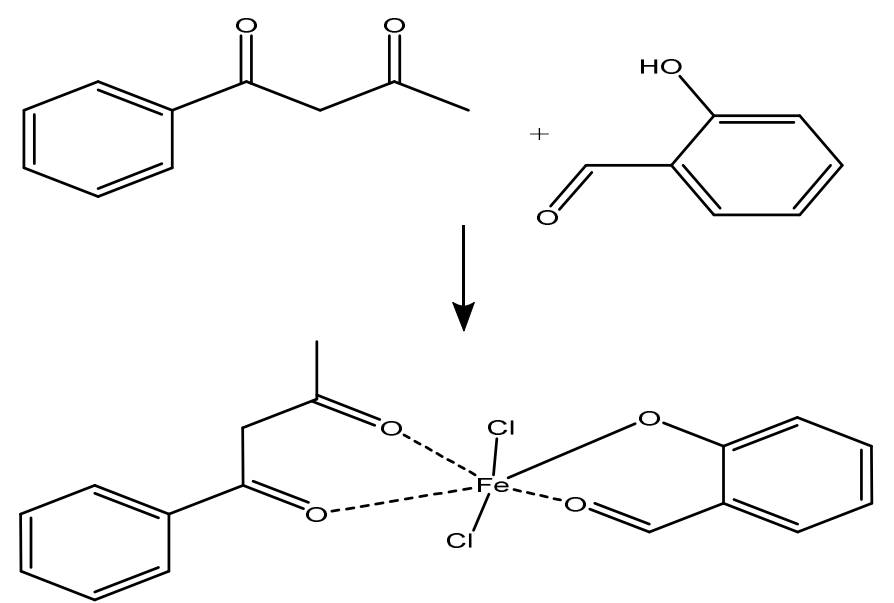

Figure 2: proposed structure of the complex with Fe (III) as the central metal

\section{CONCLUSION}

This paper has reported a series of four mixed ligand complexes synthesized by the reaction of benzoylacetone and salicylaldehyde with suitable metal chlorides in ethanolic medium. The synthesized complexes have been characterized by molar conductance measurements, thermal stabilities and

\section{REFERENCES}

Agrawal, M., Kaur, G., and A khandelwal,. (2013): Synthesis And Studies of Mixed Ligand Complexes Of Mn(II) With Salicylaldehyde And Substituted Salicylaldehydes,2Hydroxyarylcarbonyl Compounds Or $\beta$ Diketones. Journal of Applicable Chemistry.2 (6), $1472-1483$

Ahmadzadeh, R., Azarkish, M,. and T. Sedaghat (2014): synthesis, spectroscopic characterization, thermal analysis and antibacterial activity of $\mathrm{Ni}(\mathrm{II}), \mathrm{Cu}(\mathrm{II})$ and $\mathrm{Zn}$ (II) complexes with Schiff bases derived from $\beta$-Diketones. Journal of mexicon chemical society.58(2), 173-179.

Aliyu, H. N., and M. Abdullahi. (2009): Synthesis and characterization of oxovanadium (IV) $\beta-$ diketonate complexes. African Scientist. 123 126.

Bhatt VD, (2008). Synthesis, characterization, spectral studies and electrical conductivity of some tetradentate Schiff base complexes. Indian Science Congress Abstracts, 3: 60-64.

Chen , T., C. Xu, T.H. Baum, G.T. Stauf, J.F. Roeder, A.G. DiPasquale, and A.L. Rheingold, Chem.Mater.,2010, 22, 27

Dawood, Z.F., and M.W. Ibrahim, (2008):Preparation of Some Nickel (II) Complexes Containing Mixed Ligands (Salicylaldehyde Semicarbazone and Carboxylic Acids).National Journal of Chemistry. 30, 330-337.

Dnyaneshwar, S.W., Nileshkumar, D.M., and Atit, H.Q., (2014): mixed ligand complexes derived from 4-(benzenazo) salicylaldehyde and 2-amino-4nitrophenol using transition metal ions. Journal spectral techniques such as IR and Uv-vis electronic spectra. On this basis and the literature obtained, it can be suggested that, three (3) five coordinated trigonal bipyramidal complexes and one (1) six coordinated octahedral complexes were formed. The complexes showed high thermal stability.

of current chemical and pharmaceutical sciences. 4(3), 135-141.

Dul M-C, Pardo E, and R. Lescouezec (2010) : Supramolecular coordination chemistry of aromatic polyoxalamide ligands: A metallosupramolecular approach toward functional magnetic materials. Coordination Chemistry Reviews, 254: 2281-2296.

El-qisairi, A.K., Qaseer, A.H., Zaghai, M.H., Magaireh, S., Saymeh, R. and A.Y. Yousef, (2007): Synthesis, characterization and NMR studies of some 2,6-diaminopyridine complexes with palladium(II) Rhodium(III) and Mercury(II). Jordan journal of chemistry. 2(3), 255-264.

Keskioglu E, Gunduzalp A.B, and S. Cete (2008) : $\mathrm{Cr}(\mathrm{III}), \mathrm{Fe}(\mathrm{III})$ and $\mathrm{Co}(\mathrm{III})$ complexes of tetradentate (ONNO) Schiff base ligands: Synthesis, characterization, properties and biological activity. Spectrochimica Acta, 70A: 634-640. Journal of Biochemistry, 2000,65, 961

Halli, M.B., Vijayalaxmi P. B., Sumathi, R.B., and,K. Mallikarjun (2012):Synthesis, characterization and biological activity of mixed ligand metal (II) complexes derived from benzofuran-2carbohydrazide schiff base and malonyldihydrazide. Der Pharma Chemica.4(6). 2360-2367.

Jian-ning L., Bo-wan W., Bing Z., and L. Yongchun, (2006); Synthesis and Characterization of Metal Complexes of $\mathrm{Cu}(\mathrm{II}), \mathrm{Ni}(\mathrm{II}), \mathrm{Zn}(\mathrm{II})$, $\mathrm{Co}(\mathrm{II}), \mathrm{Mn}(\mathrm{II})$ and $\mathrm{Cd}(\mathrm{II})$ with Tetradentate Schi- Bases Turk J Chem 30 , 41-48. 
Malghe , Y. S., R. C. Prabhu and R. W. Raut,(2009): mixed ligand complexes derived from 4(benzeneazo) salicyladehyde and 2-amino-4nitrophenol using transition metal ions Acta Polo. Pharma. \& Drug Res., 66(1) 45.

Malathy, M., Srividhya, C., and Rajavel, R.(2014): Antimicrobial Activities of $\mathrm{Co}(\mathrm{II}), \mathrm{Ni}(\mathrm{II}), \mathrm{Cu}(\mathrm{II})$ and Zn(II) Metal Complexes Derived from Tetradentate Schiff Base Ligands. The International Journal of Science \& Technoledge.

Matsukura, T, and H Tanaka, (2000) : Studies on Biological Activities of Some Chiral Cobalt Complexes

Mrinalini, L and A. K. Manihar Singh, (2012): Mixed Ligand Cobalt (III) Complexes with 1-AmidinoO-Methylurea and Amino Acids. Res. J. Chem. Sci., 2(1), 45

Mumthaz, A,K., and. G. Parameswaran,(2010): Physicochemical Studies and Thermal Decomposition Kinetics of Some Metal Complexes of Dibenzoylmethane L-Histidine.Asian Journal of Chemistry. 22(1), 61-65.

Ndosiri N.B, M. O. Agwara, A. G. Paboudam, P. T. Ndifon, D. M. Yufanyi and Amah C., (2013) Res. J.Pharma., Bio. Chem. Sci., 4(1), 386.

Oladipo, M, A., , O, S. Bello, \& Adeogbo A, I. (2013): Synthesis, Characterization and Kinetic Studies of Nickel (II) Complex of Dibenzoyl Methane and It's Adduct. Chemistry and Materials Research. 3 (9).Janes,

Patel, R.N., Singh N., Gundla V.L.N, and U.K. Chauhan, (2007): Novel copper(II)dienimidazole/imidazolate-bridged copper(II) complexes. Crystal structure of
$[\mathrm{Cu}($ dien $)(\mathrm{Him})]\left(\mathrm{ClO}_{4}\right)_{2}$ and of $[($ dien $) \mathrm{Cu}(\mathrm{mu}-$ im) $\mathrm{Cu}$ (dien) $]\left(\mathrm{ClO}_{4}\right)_{3}$, a homobinuclear model for the copper(II) site of the CuZn-superoxide dismutase. Spectrochim. Acta. 66(3), 726-731

Prushan MJ, Tomezsko D.M, and S. Lofland (2007): A nickel(II) di-l2-phenolato bridged dinuclear complex: Weak antiferromagnetic interactions in nickel(II) dimers. Inorganica Chimica Acta, 360: 2245-2254.

Reddy , P.R., M. Radhika, and P. Manjula, (2005): Synthesis and characterization of mixed ligand complexes of $\mathrm{Zn}(\mathrm{II})$ and $\mathrm{Co}(\mathrm{II})$ with amino acids: Relevance to zinc binding sites in zinc fingers. J. Chem. Sci., 117, 239-246

Sanap, S. V. and R. M. Patil (2013): Synthesis, Characterisation and Biological Activity of Chiral Mixed Ligand of $\mathrm{Ni}(\mathrm{II})$ Complexes Res. J. Pharma. Sci., 2(1), 1 (2013).

Shaker , S. A., Y. Farina and A. A. Salleh, (2009) : Synthesis, Spectral and Antimicrobial Studies on Mixed Ligand Cu(II) Complexes of Schiff Base 2-Amino-4-Nitrophenol-NSalicylidene and SomeAmino Acids J. Sci. Res., 33(4), 702 (2009).

Kashar, T. I. (2014): Synthesis, Characterization And Biological Activity Of Some Metal Complexes Of Benzoylacetone Schiff Base. Eur. Chem. Bull., 2014, 3(9), 878-882

Venegas-Yazigi D, Aravena D, and E. Spodine „, 2010. Structural and electronic effects on the exchange interactions in dinuclear bis(phenoxo)-bridged copper(II) complexes. Coordination Chemistry Reviews, 254: 20862095. 